\title{
PEACEFUL MEANS OF RESOLVING INTERNATIONAL DISPUTES
}

\section{Halytska Anastasiia ${ }^{1}$}

DOI: https://doi.org/10.30525/978-9934-571-89-3_55

An international dispute is a specific political-legal relationship that arises between two or more subjects of international law and reflects the contradictions that exist within these relations. That is, it is a dispute that arises between States or other entities on the issue of legal fact or legal regulation of certain relations.

In the UN Charter for the qualification of conflict relations, the terms "dispute" and "situation" are used, but their definitions are not given. In accordance with the doctrine of international law, as well as the practice of the Security Council and the International Court of Justice

- The dispute occurs in the event that the States mutually present claims regarding the same subject matter;

- the situation arises when the collision of the interests of the states is not accompanied by the mutual presentation of claims, although it creates a misunderstanding between them [1, p. 283].

Thus, the situation is a wider category than a dispute.

The existence of certain differences does not yet determine the existence of a dispute between States. Upon recognition of the existence of a dispute, there is a duty

\footnotetext{
${ }^{1}$ Law College of National University “Odessa Law Academy”, Ukraine
} 
to resolve this dispute. The international dispute should be resolved only by peaceful means, based on the principle of peaceful resolution of international disputes.

The classification of international disputes in the scientific literature is carried out according to different criteria:

1) the degree of security for international peace;

2) by object or subject of dispute (political, legal, economic, social, militarypolitical);

3) for spatial distribution (local, regional, global);

4) by the range of subjects or parties (bilateral, multilateral). The most widespread are political and legal international disputes [2, p. 468].

They may arise in various spheres of state activity, in relation to the interpretation or application of an international treaty, in the event of a question of liability, etc. (legal disputes). Political disputes are not transferred to the courts and arbitration proceedings, but resolved by political means.

According to the UN Charter, the division of international disputes into such matters, whose continuation may threaten the maintenance of international peace and security, and disputes that do not have such features (Article 33), is important. The first in the doctrine is called qualified, the latter - ordinary.

A number of international legal acts regulated peaceful means of resolving international disputes long before the UN Charter. In 1889, the I Hague Peace Conference established a commission on mediation and arbitration and adopted the Convention on the Peaceful Settlement of International Disputes. In 1907, the II Hague Peace Conference revised the adopted convention, and in 1928 the Paris Treaty "On the Abandonment of War" (Briana-Kellogg Pact) was subsequently adopted, subsequently the Final Act of the Conference on Security and Cooperation in Europe of 1975, the Manila Declaration on Peace settlement of disputes in 1982.

Thus, the main sources of peaceful means of resolving international disputes are:

- Convention "On the Peaceful Settlement of International Disputes", 1907;

- UN Charter 1945;

- Final Act of the Conference on Security and Cooperation in Europe of 1975;

- Principles of dispute settlement and the provisions of the CSCE peace-keeping resolution of disputes of 1991.

In general, there are two main ways of resolving international disputes: diplomatic and judicial. Diplomatic procedures do not always lead to an effective and final settlement of disputes, since the states participating in the dispute reserve the right to make a final decision. In the application of judicial procedures, the state agrees and obeys a decision whose contents they are not known at the beginning of the procedure [3, p. 543].

The mentioned international legal instruments list such peaceful means of resolving international disputes: negotiations, inspections, mediation, reconciliation, arbitration, court proceedings, appeals to regional bodies or agreements, as well as other means. Negotiations, surveys, mediation, good services, reconciliation are among the diplomatic ways to resolve international disputes; Litigation is an international judicial institution, arbitral tribunal and arbitration. 
If all possible means have not helped and there is a dispute, it is important to determine precisely the date of its occurrence (in the case of a war, for example, depending on the international legal status of the status of neutral states, the calculation of the compensation to be provided, there is often an opportunity to appeal to the judiciary, etc.). However, it is difficult to formulate a general rule regarding the date of the occurrence of international disputes.

In general, disputes arise when the subjects clearly demonstrate or express their disagreement with the law, claims or behavior of another entity. However, in practice, widespread situations where relations have deteriorated, tensions have been created, pre-conflict situations have been created, and, with mutual consent, even after a dispute that can reach a high intensity, the dispute may disappear. In legal categories, it is difficult to take into account the diversity and complexity of specific cases.

\section{References:}

1. Pronyuk N.V. (2010). Suchasne mizhnarodne pravo [Contemporary International Law]. Kyiv: KNT. (in Ukraine)

2. Syrojid T.L. (2018). Mizhnarodne publichne pravo [International Public Law]. Odessa: Feniks. (in Ukraine)

3. Telipko V.E., Ovcharenko A.S. (2010). Mizhnarodne publichne pravo [International Public Law]. Kyiv: Centr uchbovoji literatury. (in Ukraine) 